\title{
Lipase Production using Aspergillus japonicus MF-1 through Biotransformation of Agro-Waste and Medicinal Oil Effluent
}

\author{
Nathan Vinod Kumar ${ }^{1,2 *}$, Mary Esther Rani ${ }^{1}$, R. Rathinasamy Gunaseeli ${ }^{3}$ \\ and Narayanan Dhiraviam Kannan ${ }^{4}$
}

\author{
${ }^{1}$ Research Centre, Department of Botany and Microbiology, Lady Doak College, Madurai - \\ 625002, Tamil Nadu, India \\ ${ }^{2}$ National Institute of Oceanography-CSIR, Regional Centre, Cochin 682018, Kerala, India \\ ${ }^{3}$ Center for Environmental Studies, Lady Doak College, Madurai -625002, India \\ ${ }^{4}$ Department Plant Biotechnology, School of Biotechnology, Madurai Kamaraj University, \\ Madurai-62502i, Tamil Nadu, India \\ *Corresponding author
}

\begin{tabular}{|c|c|}
\hline & A B S T R A C T \\
\hline $\begin{array}{l}\text { Lipase, Solid-state } \\
\text { fermentation, } \\
\text { Enzyme activity, } \\
\text { Oil cakes, Oil } \\
\text { effluent, } \\
\text { Optimization. }\end{array}$ & \multirow{3}{*}{$\begin{array}{l}\text { Oil rich effluents are always a menance for many industries in the process of effluent } \\
\text { treatment. The process usually requires more complex methods to resolve the issue to } \\
\text { reach to disposable effluent standards. Enzymatic degradation was proved to be promising } \\
\text { for the efficient treatment of oil rich effluents. Among the hydrolytic enzymes, lipases are } \\
\text { the second most widely-used enzymes in industrial applications. A potential lipolytic } \\
\text { fungus obtained from a marine soil sample exposed to oil spillage was identified as } \\
\text { Aspergillus japonicus MF-1. A maximum activity of } 266 \mathrm{U} / \mathrm{g} \text { was observed using solid } \\
\text { state fermentation (SSF) utilizing groundnut oil cake. Lipase activity was found to be } \\
\text { enhanced by oxidizing and reducing agents. Medicinal oil effluent was biotransformed to } \\
\text { produce lipase under submerged fermentation to achieve a maximum activity of } 153.4 \\
\text { U/ml. For lipase production using A. japonicus MF-1, solid state fermentation was found } \\
\text { to be a cost effective and better strategy. Moreover, the usage of medicinal oil like } \\
\text { effluents for lipase production is quite promising for bio-remediation of oil rich effluents. }\end{array}$} \\
\hline Article Info & \\
\hline $\begin{array}{l}\text { Accepted: } \\
\text { 15 March } 2017 \\
\text { Available Online: } \\
10 \text { April } 2017\end{array}$ & \\
\hline
\end{tabular}

\section{Introduction}

Lipases (EC 3.1.1.3) the most versatile enzyme class are enzyme that hydrolyzes triacyl glycerides liberating fatty acids. They possess unique characteristics like substrate specificity, region-specificity and chiral selectivity (Castro-Ochoa et al., 2005). The use of this enzyme has enormous potential to reduce energy requirements and solve many environmental problems especially related to industrial effluents (Pereira et al., 2013). The lipase enzyme is widely used in many industries including textile, food, pulp and paper, fat and oleo chemical, pharmaceutical and more recently in biofuel industries (Singh and Mukhopadhyay, 2012). Lipases could be used for removal of hydrophobic components of wood consisting mainly of triglycerides and waxes, which cause severe problems in paper manufacturing process. There are many fungi utilized for the application of lipase production. Among them, Aspergillus, Penicillium and Rhizopus are the most 
common and potential genera for lipase production. Aspergillus $s p$. is widely used for the production of hydrolytic enzymes such as amylase and lipase on commercial scale (Perrone et al., 2008). A. japonicus isolated form olive oil mill waste exhibited lipolytic as well as cellulolytic activity (Gopinath et al., 2005).

Submerged fermentation has its own advantages in the consideration of scaling up in industrial level. There are reports on utilization of oil mill and winery waste for the lipase production (Salgado et al., 2014). However the factors to achieve the maximum enzyme activity may vary from each species and there is a need for optimization of the production medium. Filamentous fungi have the ability to grow on solid substrates and produce many extracellular enzymes (Vishwanatha et al., 2010). Due to the lower production cost, solid state fermentation which usually utilizes the agro-waste as substrates is the best strategy for enzyme production on a commercial scale. Gombert et al., (1999) reported the use of babassu oil cakes for lipase production using Penicillium restrictum. Other agro-waste utilized for lipase production includes brans (wheat, rice, soyabean and barley), oil cakes (soy, olive and gingelly) and sugarcane bagasse (Godoy et al., 2011; Salihu et al., 2012).

The present work focuses on achieving maximum lipase activity from $A$. japonicus under submerged and solid state fermentation (SSF) and to make a comparison of submerged and SSF. The oil cakes and effluents rich in oil were also utilized for lipase production using the fungal isolate. A high lipase activity was achieved using submerged as well as under SSF by $A$. japonicus MF-1 isolate. Production optimization and kinetics were studied in detail using suitable statistical models.

\section{Materials and Methods}

\section{Isolation and screening of lipolytic fungi}

Oil contaminated soil samples from mangrove and coastal environments of Kerala and Tamil Nadu were collected aseptically. Serial dilution was performed up to $10^{-6}$ dilution to isolate the distinct fungal colonies on Potato Dextrose Agar (PDA) plates at $28 \pm 2{ }^{\circ} \mathrm{C}$ after 3-5 days of incubation. Isolated fungal colonies were further stored on PDA slants for screening. Primary screening was performed on PDA plates fortified with $2 \%$ olive oil as substrate and supplemented with $0.5 \%$ phenol red as $\mathrm{pH}$ indicator. Lipolytic fungal strains converted substrate into simpler fatty acids and changed the $\mathrm{pH}$ of the medium from pink to yellow (Singh et al., 2006). Change in plate colour was considered positive for lipolytic activity. Secondary screening was performed by quantification of lipase activity using standard method described in the following section.

\section{Molecular characterization of fungal isolate}

DNA was isolated from the fungal isolate by using the method reported earlier (Melo et al., 2006). Quality of the DNA was evaluated by spectrometric analysis as well as by performing electrophoresis on $0.8 \%$ agarose gel. DNA was further amplified using DR [5'GGTCCGTGTTTCAAGACGG-3'] and DF [5'-ACCCGCTGAACTTAAGC-3'] universal primers for amplification of LSU 28S rDNA (Kurtzman and Robnett, 1997). The PCR reaction was performed using the method described by Vinod et al., (2014). Resultant PCR amplicon was purified and sequenced using automated DNA sequencing on ABI 3730xl DNA analyzer (Applied Biosystems, USA). The sequencing chromatogram was analyzed to extract the sequence and used for BLASTn analysis against non-redundant 
NCBI database which resulted in the identification of ten similar sequences. Clustal W multiple sequence alignment (Thompson et al., 1994) was performed using BioEdit 5.0 and phylogenetic tree was constructed for the aligned sequences in MEGA 5.0 (Tamura et $a l ., 2011$ ) based on neighbour joining method (Saitou and Nei, 1987).

\section{Lipase assay}

Lipase assay was performed using standard method which is described as follows. $2.5 \mathrm{ml}$ of water was added into test and blank test tubes followed by $1 \mathrm{ml}$ of $100 \mathrm{mM}$ Tris $\mathrm{HCl}$ buffer [pH 7.2]. $3 \mathrm{ml}$ of olive oil was added as the substrate and mixed well and incubated for $5 \mathrm{~min} .1 \mathrm{ml}$ of enzyme was added into test sample and incubated for $30 \mathrm{~min}$ at room temperature. After the incubation, $1 \mathrm{ml}$ of 95\% ethanol was added to stop the reaction and titrated against $0.1 \mathrm{M} \mathrm{NaOH}$ with $0.9 \%$ phenolphthalein as an indicator. Appearance of pale pink colour was considered as end point. One unit of lipase is defined as the amount needed to hydrolyze 1.0 microequivalent of fatty acid from a triglyceride in one hour at $\mathrm{pH} 7.7$ at $37^{\circ} \mathrm{C}$.

\section{Utilization of ayurvedic oil effluent for lipase production}

Ayurvedic pharmaceutical effluent rich in oil and higher forms of hydrocarbon were obtained from commercial ayurvedic drug manufacturer's in Madurai, Tamil Nadu. It was made into different concentrations of 25 , 50 and $100 \%(\mathrm{v} / \mathrm{v})$ using phosphate buffer [pH 8.2]. A. japonicus MF-1 was inoculated into the sterilized effluent which was used as sole production media component and incubated under shaking condition at $120 \mathrm{rpm}$ for 5-7 days at room temperature. Lipase enzyme was extracted using centrifugation of culture at $8000 \mathrm{rpm}$ for $5 \mathrm{~min}$ and obtained supernatant was used to perform enzymatic assay during $5^{\text {th }}$ and $7^{\text {th }}$ day of incubation.

\section{Solid state fermentation using oil cakes}

The solid state fermentation was considered as a common strategy for reducing the enzyme production cost. For the same, effect of various factors was tested using PlackettBurman design based on the first order model (Plackett and Burman, 1964). The factors optimized and values coded were enlisted in Table 1. Statistically validation of the model was also done using Design Expert 9.0 software. Significant parameters identified from Plackett-Burman designs were selected for Box-Behnken design to obtain response surface curve for the enzyme production. Each factor was studies at two different levels (- 1 and +1) (Table 4). A set of 17 experiments were carried out.

\section{Kinetics of lipase enzyme}

Kinetics of Lipase enzyme activity was studied by plotting a Lineweaver- Burk (LB) Plot. $\mathrm{K}_{\mathrm{m}}$ and $\mathrm{V}_{\max }$ of the enzyme was predicted. Effect of different solvents, oxidizing and reducing agents on enzyme activity was also verified and the residual activity was calculated. For understanding the hydrolyzing potential of complex oils, the obtained crude lipase enzyme was used to treat olive oil. The enzyme concentrations were varied and incubated at room temperature and after $1 \mathrm{hr}$ the enzyme was inactivated at $100^{\circ} \mathrm{C}$. The release of free fatty acids was quantified using standard method (Kamini et al., 2000).

\section{Results and Discussion}

\section{Screening and identification of lipolytic fungi}

Among 12 fungal isolates screened for lipolytic activity, MF-1 was found to exhibit maximum activity in plate screening with olive oil as a substrate. Release of fatty acids changed the medium $\mathrm{pH}$ towards acidic and 
plate to yellow colour indicating lipase producing ability of the isolate. Secondary screening i.e., lipase assay also revealed that MF-1was the most potent lipolytic fungi. Based on the colony morphology and by microscopic observation of the LCB mount, MF1 was identified as Aspergillus sp. MF-1 was identified as Aspergillus japonicus through the chromatogram analysis and Blastn analysis of the sequence (D1/D2 region LSU). Further the sequence was submitted in GenBank and an accession number was obtained as KF922321.

\section{Hydrolysis of oil substrates}

Hydrolysis of olive oil as a substrate was tested based on the lipase enzyme produced. Varying enzyme dosage (v/v) was used to treat the substrate and free fatty acids released on hydrolysis were estimated. There was an increase in the free fatty acids released with increasing enzyme dosage. The potential of hydrolyzing ability of complex hydrocarbons could be exploited in treatment of oil rich effluent and as well as for the biodiesel production using complex natural oil sources. The decrease of hydrolysis beyond a period of 90 min could be due to fatty acids which could inhibit lipase activity (Goswami et al., 2012).

\section{Effluent for lipase production}

The utilization of ayurvedic oil effluent for lipase production was evaluated using three different concentrations of effluent (25\%, $50 \%$ and $100 \%$ ). The Lipase production was evaluated following $5^{\text {th }}$ and $7^{\text {th }}$ day of incubation. In $100 \%$ effluent, there was no significant fungal growth and lipase activity was observed. In case of 25 and 50\% effluent, there was fungal biomass and lipase production. However, a maximum of 153.2 $\mathrm{U} / \mathrm{ml}$ of lipase activity was achieved on $5^{\text {th }}$ day in $25 \%$ and on $7^{\text {th }}$ day in $50 \%$ effluent (Figure 3). Hence, the ayurvedic oil effluent could be utilized as a support medium along with production medium to achieve maximum lipase production using the A. japonicus MF1. Salgado et al., (2014) utilized two-phase oil mill waste, a major waste of olive mill industry and achieved a maximum lipase activity of $18.67 \mathrm{U} / \mathrm{g}$ by A.ibericu. However, this was obtained by supplementation of $0.073 \mathrm{~g}$ urea/g and $25 \%$ EGM along with the effluent which stimulated the production.

\section{Solid state fermentation using GOC}

Microbial lipases are produced mostly by submerged culture (Ito et al., 2001), but solid state fermentation methods can also be used (Chisti, 1999). Rivera-Munoz et al., (1991) verified the superiority of SSF over Submerged fermentation using Penicillium candidum for lipase production. There were many reports on the lipase production by Aspergillus sp. on SSF using oil cakes. The groundnut oil cake (GOC) was used as a substrate for lipase production using $A$. japonicus MF-1. Kamini et al., (2000) used gingelly oil cakes for lipase production using Aspergillus niger. Similarly, Christen et al., (1995) obtained lipase from Rhizopus delemar grown on a polymeric resin. Kumar and Ray (2014) used Plackett-Burman design for optimization of lipase production using a Pseudomonas sp.AKM-L5. For optimization of the most favourable conditions, PlackettBurman design was used. The tested variables and coded values were mentioned in table 1. Maximum lipase activity of $266 \mathrm{U} / \mathrm{g}$ was achieved during solid state fermentation conditions. The predicted model had $\mathrm{R}^{2}$ value of $99.05 \%$ and predicted response of $90.88 \%$. The model indicated that a high inoculum percentage of 10 with incubation temperature of $55^{\circ} \mathrm{C}$ for $168 \mathrm{hrs}$ of incubation could achieve maximum lipase activity using GOC as substrate even in lowest moisture percentage of 20 . The regression model for the optimized condition was mentioned as Equation 1. 
Table.1 Variable used in Plackett-Burman model for optimization of lipase production under SSF with high and lower values of the factors tested

\begin{tabular}{|c|c|c|c|c|}
\hline \multirow[t]{2}{*}{ Code } & \multirow[t]{2}{*}{ Variables } & \multirow[t]{2}{*}{ Units } & Low & High \\
\hline & & & -1 & +1 \\
\hline A & Moisture & $\%$ & 20 & 60 \\
\hline B & Temperature & ${ }^{\circ} \mathrm{C}$ & 28 & 55 \\
\hline $\mathrm{C}$ & $\mathrm{pH}$ & & 5 & 7 \\
\hline $\mathrm{D}$ & Inoculum & $\%(\mathrm{v} / \mathrm{w})$ & 3 & 10 \\
\hline $\mathrm{E}$ & Incubation & Hours & 72 & 168 \\
\hline $\mathrm{F}$ & $\mathrm{KH}_{2} \mathrm{PO}_{4}$ & $\mathrm{~g} / \mathrm{L}$ & 2 & 4 \\
\hline G & Peptone & $\mathrm{g} / \mathrm{L}$ & 5 & 10 \\
\hline $\mathrm{H}$ & Urea & $\mathrm{g} / \mathrm{L}$ & 1 & 3 \\
\hline $\mathrm{I}$ & Olive oil & $\mathrm{ml} / \mathrm{L}$ & 10 & 50 \\
\hline $\mathrm{J}$ & $\mathrm{KCl}$ & $\mathrm{g} / \mathrm{L}$ & 2 & 5 \\
\hline
\end{tabular}

Table.2 Lipase activity at various runs of Plackett-Burman design using A. japonicus MF-1

\begin{tabular}{|c|c|c|c|c|c|c|c|c|c|c|c|c|c|}
\hline \multirow{2}{*}{ Run } & \multirow{2}{*}{$\mathbf{A}$} & \multirow{2}{*}{ B } & \multirow{2}{*}{$\mathbf{C}$} & \multirow{2}{*}{ D } & \multirow{2}{*}{$\mathbf{E}$} & \multirow{2}{*}{$\mathbf{F}$} & \multirow{2}{*}{$\mathbf{G}$} & \multirow{2}{*}{$\mathbf{H}$} & \multirow{2}{*}{ I } & \multirow{2}{*}{$\mathbf{J}$} & \multirow{2}{*}{$\mathbf{K}$} & \multicolumn{2}{|c|}{ Lipase Activity (U/g) } \\
\hline & & & & & & & & & & & & Experimental & Predicted \\
\hline 1 & -1 & -1 & 1 & -1 & 1 & 1 & -1 & 1 & 1 & 1 & -1 & 106.4 & 106 \\
\hline 2 & -1 & 1 & 1 & -1 & 1 & 1 & 1 & -1 & -1 & -1 & 1 & 53.2 & 54 \\
\hline 3 & -1 & 1 & -1 & 1 & 1 & -1 & 1 & 1 & 1 & -1 & -1 & 266 & 265 \\
\hline 4 & -1 & 1 & 1 & 1 & -1 & -1 & -1 & 1 & -1 & 1 & 1 & 26.6 & 26 \\
\hline 5 & 1 & -1 & 1 & 1 & 1 & -1 & -1 & -1 & 1 & -1 & 1 & 26.6 & 27 \\
\hline 6 & 1 & -1 & 1 & 1 & -1 & 1 & 1 & 1 & -1 & -1 & -1 & 79.8 & 80 \\
\hline 7 & -1 & -1 & -1 & 1 & -1 & 1 & 1 & -1 & 1 & 1 & 1 & 79.8 & 79 \\
\hline 8 & 1 & 1 & 1 & -1 & -1 & -1 & 1 & -1 & 1 & 1 & -1 & 26.6 & 25 \\
\hline 9 & 1 & 1 & -1 & -1 & -1 & 1 & -1 & 1 & 1 & -1 & 1 & 133 & 133 \\
\hline 10 & -1 & -1 & -1 & -1 & -1 & -1 & -1 & -1 & -1 & -1 & -1 & 26.6 & 27 \\
\hline 11 & 1 & -1 & -1 & -1 & 1 & -1 & 1 & 1 & -1 & 1 & 1 & 159.6 & 160 \\
\hline 12 & 1 & 1 & -1 & 1 & 1 & 1 & -1 & -1 & -1 & 1 & -1 & 106.4 & 105 \\
\hline
\end{tabular}


Table.3 Analysis of Variance (ANOVA) for the factorial model on Lipase production by Aspergillus japonicus MF-1 through SSF utilizing groundnut oil cake (GOC) as substrate

\begin{tabular}{|c|c|c|c|c|c|c|}
\hline Source & $\begin{array}{l}\text { Sum of } \\
\text { Squares }\end{array}$ & df & $\begin{array}{l}\text { Mean } \\
\text { Square }\end{array}$ & $\begin{array}{c}\text { F } \\
\text { Value }\end{array}$ & $\begin{array}{c}\text { p-value } \\
\text { Prob > F }\end{array}$ & Status \\
\hline Model & 53774.56 & 8 & 6721.82 & 9.771429 & 0.043607 & significant \\
\hline B-Temperature & 1474.083 & 1 & 1474.083 & 2.142857 & 0.239443 & - \\
\hline $\mathrm{C}-\mathrm{pH}$ & 17040.4 & 1 & 17040.4 & 24.77143 & 0.015587 & $*$ \\
\hline D-Inoculum & 530.67 & 1 & 530.67 & 0.771429 & 0.444438 & - \\
\hline E-Incubation & 9964.803 & 1 & 9964.803 & 14.48571 & 0.031874 & $*$ \\
\hline $\mathrm{F}-\mathrm{KH}_{2} \mathrm{PO}_{4}$ & 58.96333 & 1 & 58.96333 & 0.085714 & 0.78878 & - \\
\hline G-Peptone & 4776.03 & 1 & 4776.03 & 6.942857 & 0.077994 & - \\
\hline H-Urea & 17040.4 & 1 & 17040.4 & 24.77143 & 0.015587 & $*$ \\
\hline J-Olive oil & 2889.203 & 1 & 2889.203 & 4.2 & 0.132842 & - \\
\hline Residual & 2063.717 & 3 & 687.9056 & & & \\
\hline Total & 55838.28 & 11 & & & & \\
\hline
\end{tabular}

[* Significant factors based on Prob $>$ F values]

Table.4 Variables used for the Lipase enzyme optimization using A. japonicus MF-1 based on Box-Behnken design

\begin{tabular}{lccc}
\hline \multirow{2}{*}{ Variables } & Units & Low & High \\
\cline { 3 - 4 } & & $\mathbf{- 1}$ & $\mathbf{1}$ \\
\hline $\mathrm{pH}$ & & 3 & 9 \\
Incubation time & $\mathrm{hrs}$ & 72 & 168 \\
Urea & $\mathrm{g} / \mathrm{l}$ & 1 & 3 \\
\hline
\end{tabular}


Table.5 Lipase activity obtained from different runs of the Box-Behnken experimental design using A. japonicus $\mathrm{MF}-1$

\begin{tabular}{ccc}
\hline Runs & \multicolumn{2}{c}{ Lipase Activity (U/g) } \\
\hline \multicolumn{3}{c}{ Experimental Predicted } \\
\hline 1 & 741 & 740 \\
2 & 684 & 684 \\
3 & 684 & 683 \\
4 & 684 & 682.5 \\
5 & 627 & 628 \\
6 & 684 & 683 \\
7 & 570 & 569 \\
8 & 684 & 684 \\
9 & 513 & 514 \\
10 & 570 & 569 \\
11 & 741 & 742 \\
12 & 627 & 627 \\
13 & 684 & 682 \\
14 & 627 & 628 \\
15 & 513 & 513 \\
16 & 231 & 232 \\
17 & 721 & 721 \\
\hline & &
\end{tabular}

Table.6 Comparison of Lipase production by Aspergillus sp.

\begin{tabular}{llll}
\hline \multicolumn{1}{c}{ Organisms } & \multicolumn{1}{c}{ Substrate Used } & $\begin{array}{c}\text { Maximum } \\
\text { Lipase activity }\end{array}$ & References \\
\hline $\begin{array}{l}\text { Aspergillus japonicus } \\
\text { MTCC 1975 Mutant ANT 4 }\end{array}$ & Production medium & $20.6 \mathrm{U} / \mathrm{ml}$ & {$[32]$} \\
\hline Aspergillus niger 11T5 & Wheat bran & $153.4 \mathrm{U} / \mathrm{gdm}$ & {$[\mathbf{3 3 ]}$} \\
\hline A.japonicus & $\begin{array}{l}\text { Malt extract, Wheat mill } \\
\text { bran, Soy flour, and Whey }\end{array}$ & $177.5 \mathrm{U} / \mathrm{ml}$ & {$[\mathbf{3 4 ]}$} \\
\hline A.japonicus LAB01 & Basal medium & $199.5 \mathrm{U} / \mathrm{ml}$ & {$[35]$} \\
\hline A. candidus URM 5611 & Almond bran licuri & $395 \mathrm{U} / \mathrm{gd} / \mathrm{s}$ & {$[\mathbf{3 6}]$} \\
\hline A.japonicus MF-1 & Groundnut oil cake & $266 \mathrm{U} / \mathrm{g}$ & Present Work \\
\hline
\end{tabular}


Table.7 ANOVA for the influence of the selected variable on xylanase production using Aspergillus japonicus MF- 1 based on Box-Behnken experimental design

\begin{tabular}{lrrrrrr}
\hline \multirow{2}{*}{ Source } & $\begin{array}{r}\text { Sum of } \\
\text { Squares }\end{array}$ & df & $\begin{array}{r}\text { Mean } \\
\text { Square }\end{array}$ & $\begin{array}{r}\text { F } \\
\text { Value }\end{array}$ & $\begin{array}{c}\text { p-value } \\
\text { Prob > F }\end{array}$ & Status \\
\hline Model & $1.764 \mathrm{E}+005$ & 7 & 25197.17 & 3.39 & 0.0462 & significant \\
A-pH & 4560.13 & 1 & 4560.13 & 0.61 & 0.4537 & \\
B-Incubation time & 90738.00 & 1 & 90738.00 & 12.20 & 0.0068 & \\
C-Urea & 12720.13 & 1 & 12720.13 & 1.71 & 0.2233 & \\
BC & 19881.00 & 1 & 19881.00 & 2.67 & 0.1365 & \\
$\mathrm{~A}^{2}$ & 24915.60 & 1 & 24915.60 & 3.35 & 0.1004 & \\
$\mathrm{~B}^{2}$ & 15069.60 & 1 & 15069.60 & 2.03 & 0.1883 & \\
$\mathrm{C}^{2}$ & 10769.81 & 1 & 10769.81 & 1.45 & 0.2595 & \\
Residual $^{\quad \text { Lack of Fit }}$ & 66925.70 & 9 & 7436.19 & & & \\
\multicolumn{1}{c}{ Pure Error } & 44832.50 & 5 & 8966.50 & 1.62 & 0.3296 & not significant \\
Cor Total & 22093.20 & 4 & 5523.30 & & & \\
\hline
\end{tabular}

Table.8 Effect of solvents on activity of lipase from A. japonicus MF-1

\begin{tabular}{ccc}
\hline Organic Solvents & Concentrations (\%) & Relative Activity (\%) \\
\hline Control & 0 & 100 \\
\hline \multirow{3}{*}{ Acetone } & 5 & 100 \\
& 10 & 56.4 \\
Ethanol & 15 & 32 \\
\cline { 2 - 3 } & 5 & 96 \\
& 10 & 92.4 \\
Methanol & 15 & 78 \\
\cline { 2 - 3 } & 5 & 100 \\
Hexane & 10 & 140 \\
& 15 & 173 \\
\cline { 2 - 3 } DMSO & 5 & 60 \\
& 10 & 32 \\
\cline { 2 - 3 } & 15 & 27.5 \\
\hline
\end{tabular}


Table.9 Effect of oxidizing and reducing agents on activity of lipase produced by $A$. japonicus $\mathrm{MF}-1$

\begin{tabular}{ccc}
\hline $\begin{array}{c}\text { Oxidation/reducing } \\
\text { agents }\end{array}$ & Concentrations (\%) & Relative Activity (\%) \\
\hline Control & 0 & 100 \\
\hline \multirow{2}{*}{$\mathbf{H}_{2} \mathbf{O}_{2}$} & 5 & 94.5 \\
& 10 & 80 \\
& 15 & 40 \\
\cline { 2 - 3 } & 5 & 310 \\
& 10 & 290 \\
& 15 & 380 \\
\hline
\end{tabular}

Figure.1 Neighbour Joining tree showing evolutionary relationship among other Aspergillus $s p$. and the present isolate A. japonicus MF-1

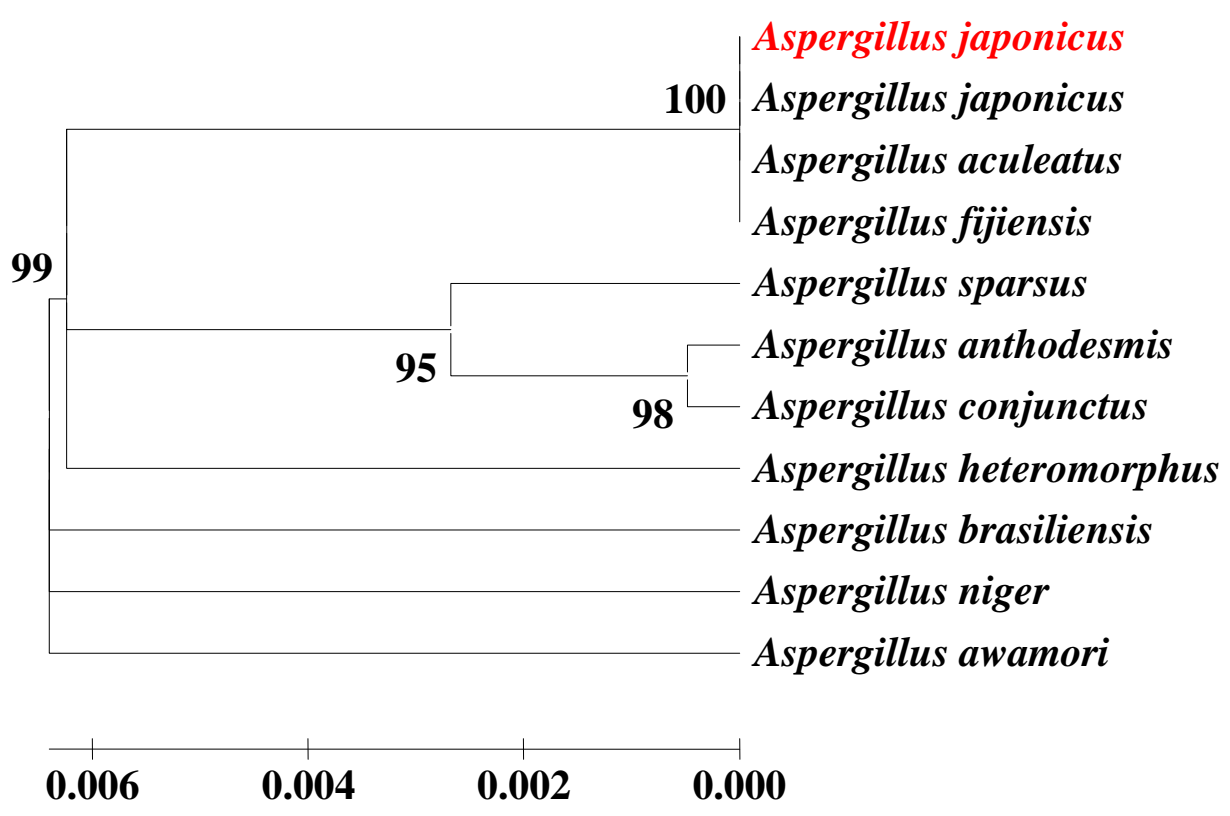


Figure.2 Kinetics showing hydrolysis of olive oil substrate using A. japonicus MF-1 lipase and release of free fatty acids

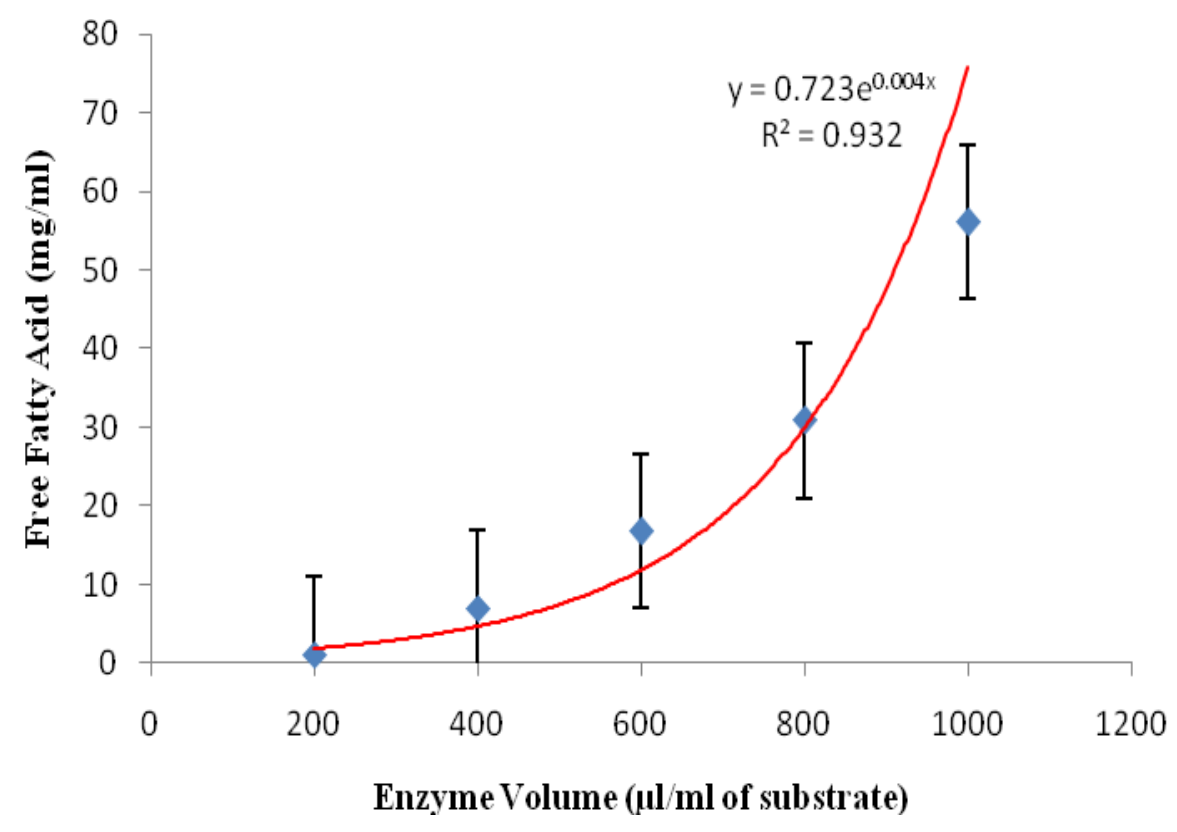

Figure.3 Medicinal oil effluent based medium for lipase production using A.japonicus MF-1 [MM- Minimal medium; E- Enzyme dosage]

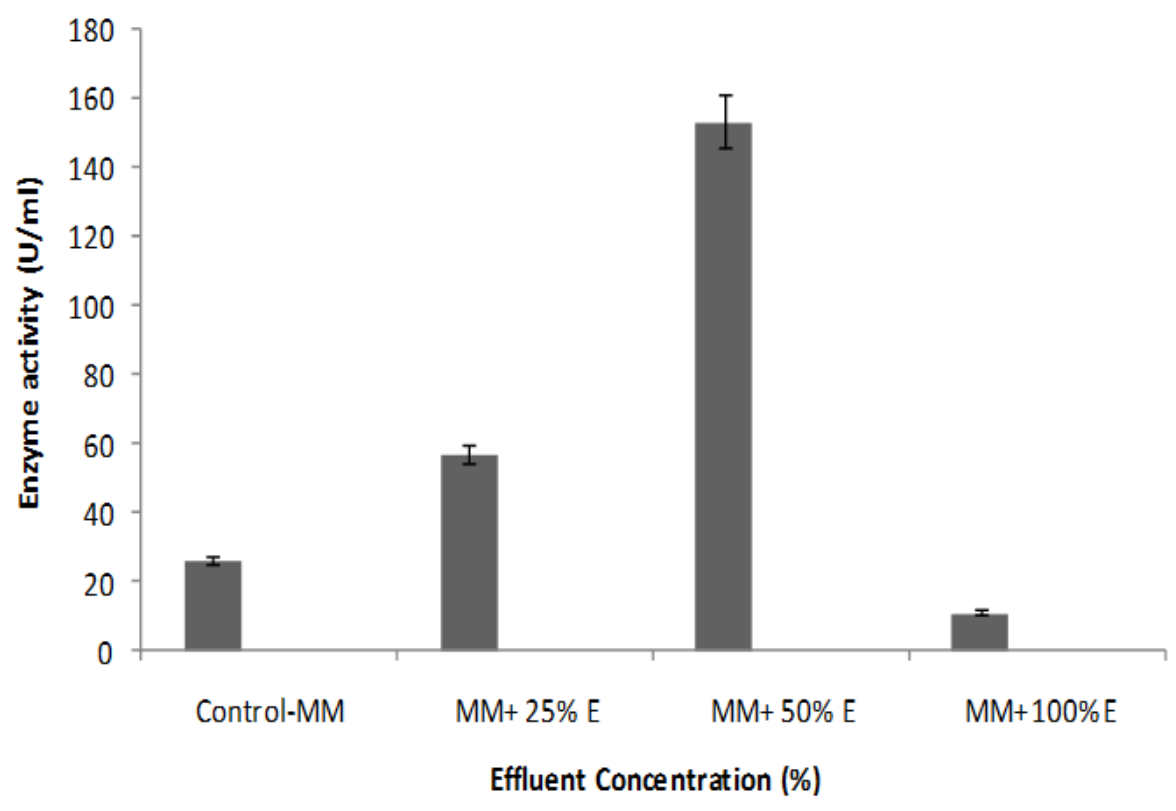


Figure.4 Contour plots showing effect of selected parameters during lipase optimization through SSF using A. japonicus MF-1 based on Plackett-Burman method

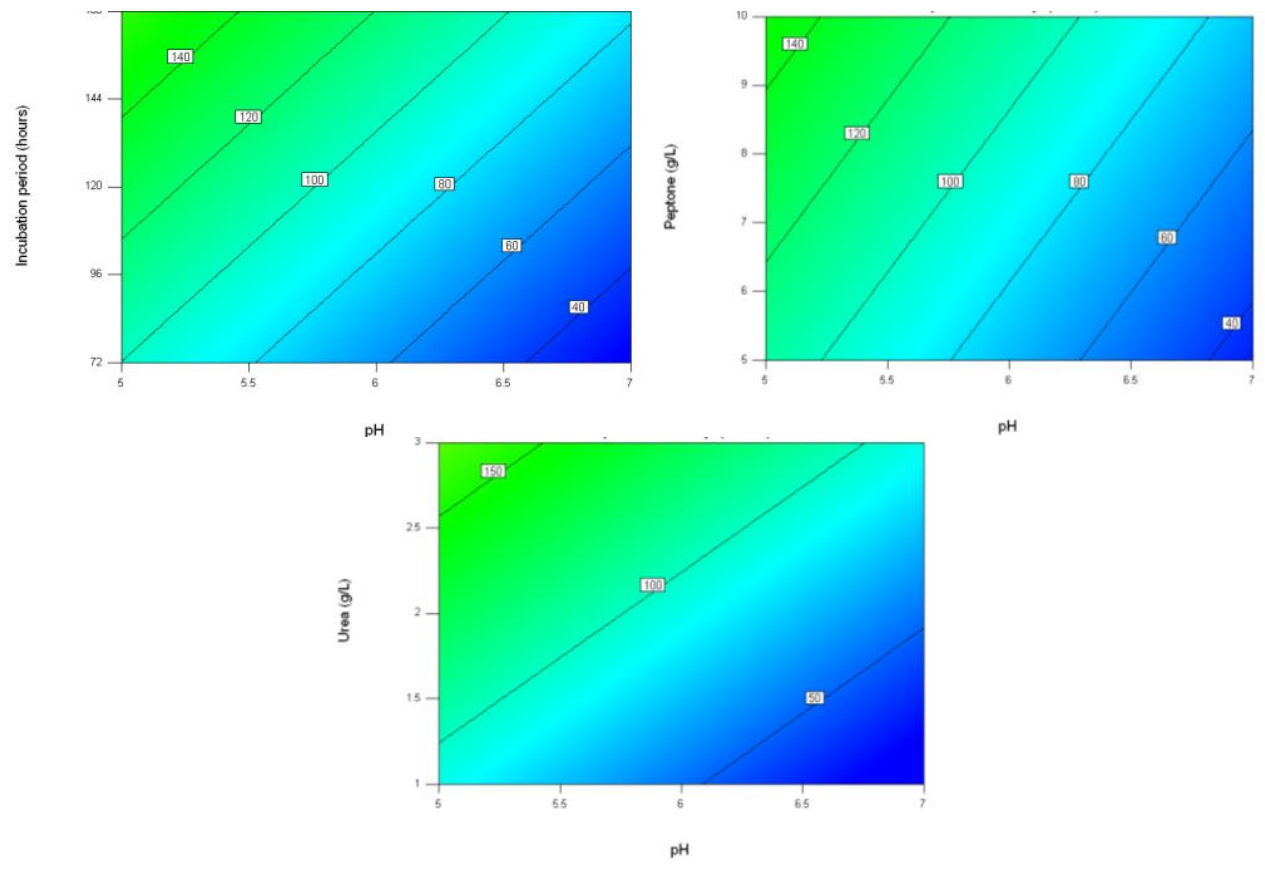

Figure.5 Contour plots showing effect of significant parameters during lipase optimization through SSF using A. japonicus MF-1 based on Box-Behnken method

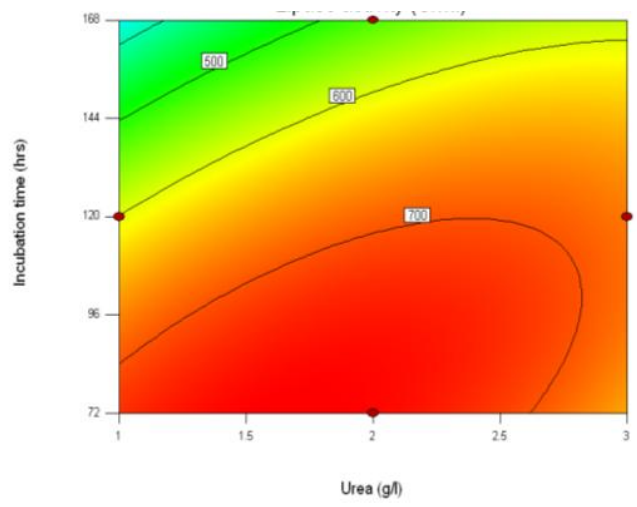


Int.J.Curr.Microbiol.App.Sci (2017) 6(4): 2005-2020
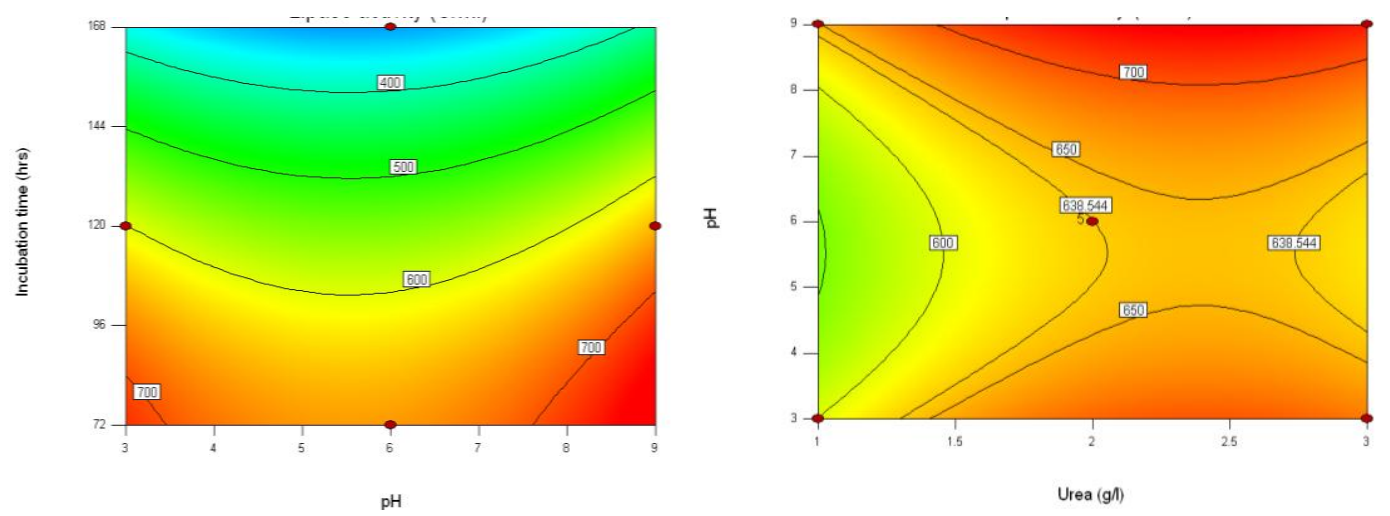

Figure.6 Kinetics and Physico-chemical property of Lipase from A. japonicus MF-1 a) Lineweaver- Burk plot showing kinetics of lipase enzyme

b) Optimum temperature and c) optimum $\mathrm{pH}$
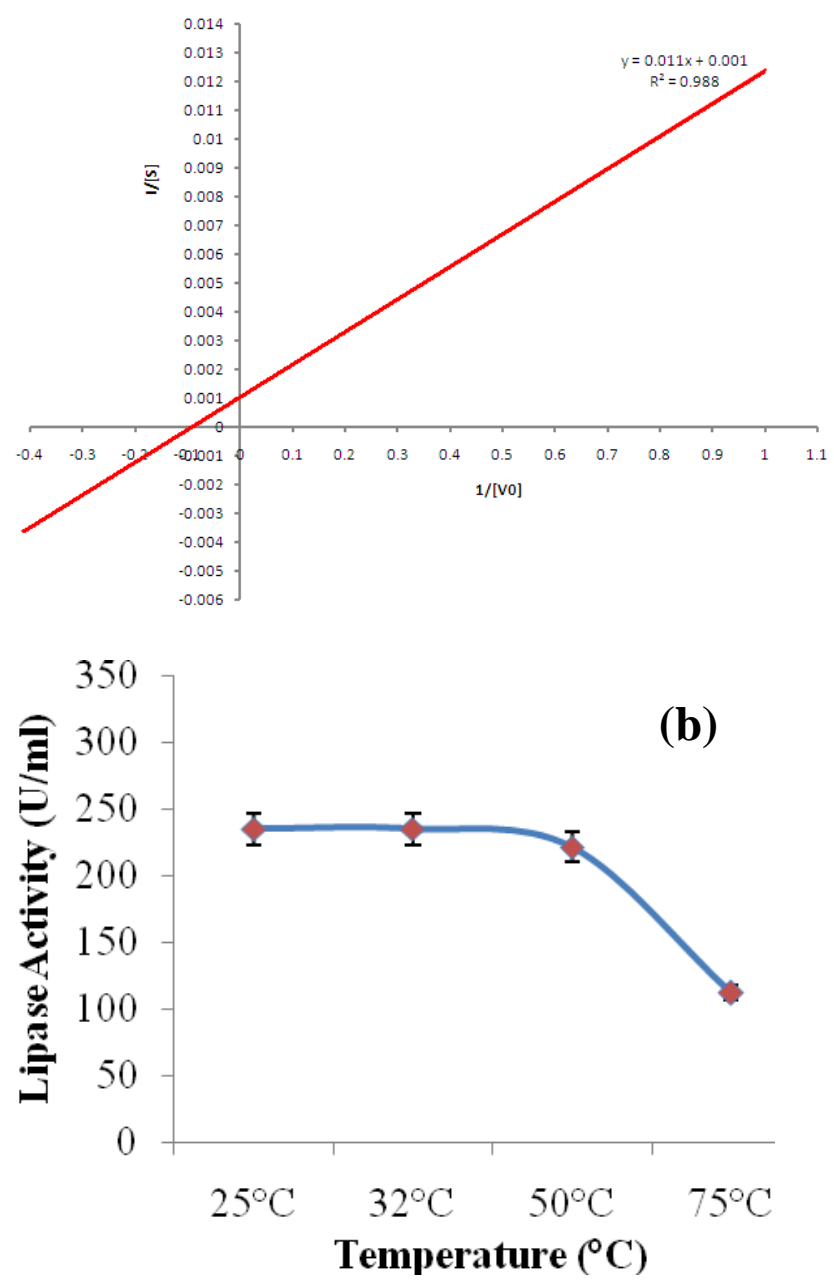

(c) 


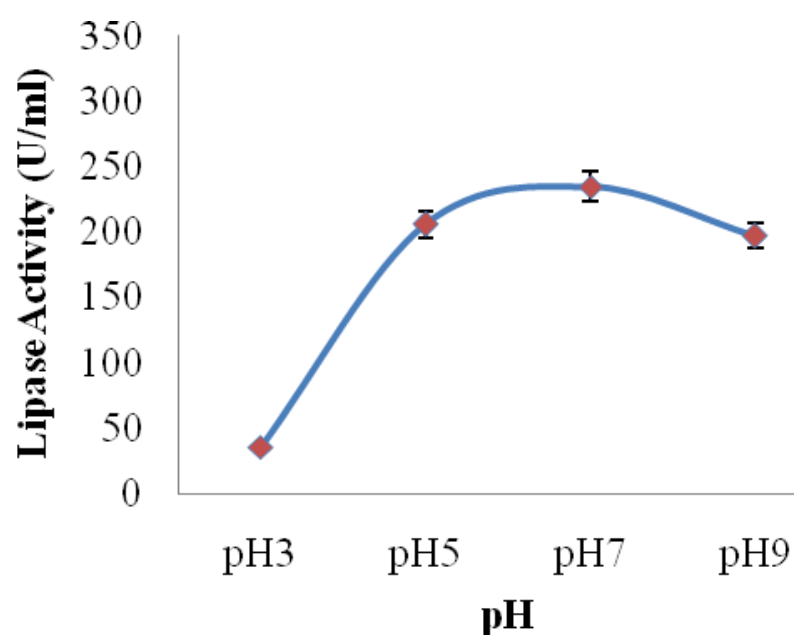

There were variations between actual and predicted model with a difference in $\mathrm{R}^{2}$ values. The actual response and the predicted values were enlisted in table 2 . Based on the ANOVA results, moisture percentage was identified as the most influential factor from this study (Table 3). Figure 4 depicts the 3D response graphs of the significant factors on lipase activity.

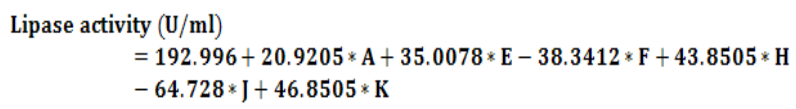

\section{Equation 1}

Where $\mathrm{Y}=$ Lipase activity $(\mathrm{U} / \mathrm{ml})$

Behnken Optimization Design for Lipase production using Aspergillus japonicus MF-1

In Lipase optimization, medium $\mathrm{pH}$, incubation time and urea concentration was varied during Box-Behnken experimental design. It was found that a maximum lipase activity of $741 \mathrm{U} / \mathrm{g}$ was achieved from the model (Table 5). The predicted model was found to be significant with a $\mathrm{R}^{2}$ value of 0.7249 (Table 7). The quadratic regression equation describing the model was written as Equation 2. Response surface curve and contour plots revealed that $\mathrm{pH}$ and urea was the most significant factor for lipase production with high response at high and low variables tested. Similarly, with high urea concentration and towards alkaline $\mathrm{pH}$, minimum incubation time was required for maximum lipase production (Figure 5). Lanka and Latha (2015) optimized lipase production using Emericella nidulans NFCCI 3643based on Box-Behnken design which resulted in an enzyme activity of $409.723 \mathrm{U} / \mathrm{ml}$, which was 2.76-fold higher than the value obtained through traditional OFAT (one factor at a time) method. However, a high lipase activity was achieved using the A. japonicus MF-1 compared to other Aspergillus sp. (Table 6).

Lipase activity $(\mathrm{U} / \mathrm{ml})=+861.14375$ $94.60833 * \mathrm{pH}+1.07552 *$ Incubation time $+65.92500 *$ Urea $+1.46875 *$ Incubation time * Urea $+8.54722 * \mathrm{pH}^{2}-0.025966 *$ Incubation time ${ }^{2}-50.57500 *$ Urea $^{2}$

\section{Equation 2}

\section{Enzyme kinetics of lipase}

The $\mathrm{K}_{\mathrm{m}}$ and $\mathrm{V}_{\max }$ values were determined using LB plot constructed (Figure 6a). The $\mathrm{K}_{\mathrm{m}}$ and $\mathrm{V}_{\max }$ values of the A. japonicus $\mathrm{MF}-1$ were found to be $11 \mathrm{mML}^{-1}$ and $1 \mathrm{Mmin}^{-1}$ respectively. The effect of various solvents on the residual activity of the lipase enzyme was calculated and tabulated in table 8 . The effect 
of various organic solvents on lipase activity was studied earlier. DMSO and methanol could enhance the lipase residual activity which was higher than previous reports. Kamini et al., (2000) achieved about a maximum of about $124 \%$ residual activity in the presence of $10 \%$ DMSO. Similarly, Akkaya and Yenidunya (2012) reported an increase of $260 \%$ and $170 \%$ of residual activity with some other solvents like 2-3, epoxypropyl methacrylates and hydroxymethyl methacrylate (HEMA). Similarly, the effect of oxidizing and reducing agents were also evaluated (Table 9).

The reducing agent mercaptoethanol could enhance the residual lipolytic activity; however the oxidizing agent lowered the activity. This was contradicting the early reports which might be due to the high concentration of $\mathrm{H}_{2} \mathrm{O}_{2}$ used in the present study. Mander et al., (2014) reported the enhancing effect of lipase residual activity of reducing agent like mercaptoethanol and $\mathrm{H}_{2} \mathrm{O}_{2}$ an oxidizing agents. The optimum Lipase activity was observed at $\mathrm{pH} 7$ and between temperature ranges of $32-50^{\circ} \mathrm{C}$ (Figure 6b and c). Mahadik et al., (2002) produced acidic lipase from Aspergillus niger through solid state fermentation.

In conclusion lipase production using $A$. japonicus $\mathrm{MF}-1$ utilizing ground nut oil cake as a substrate in solid state fermentation was found to be promising and economic. The lipase enzyme obtained exhibited higher residual activity in the presence of oxidizing and reducing agents. Submerged fermentation utilizing medicinal oil effluent for lipase production open up new scope of using the isolate in bio-remediation of oil rich industrial effluents through hydrolysis of such complex oils and further prospected its utility as a biofuel.
Acknowledgement: Authors are thankful to Department of Science and Technology, Government of India and TNSCST for providing the grant to facilitate the research [Sanction order no. DST/SSTP/TN/2K 10/126(G) 13-09-2011]. Authors thank Management and Department of Botany and Microbiology, Lady Doak College, Madurai for providing the facilities and supporting the work.

\section{References}

Akkaya, B., and Yenidunya, A.F. 2012. Properties of extracellular lipase from a traditional yoghurt yeast, Turkish $J$. Biochem., 37(1): 62-67.

Castro-Ochoa, L.D., Rodriguez-Gomex, C., Valerio-Alfaro, G., and Oliart, R.R. 2005. Screening, purification and characterization of the thermoalkalophilic lipase produced by Bacillus thermoleovorans CCR11, Enzyme Microbial Technol., 37: 648654.

Chisti, Y. 1999. Solid state fermentations, enzyme production, food enrichment. In: Flickinger, MC, Drew SW, editors. Encyclopedia of bioprocess technology: fermentation, biocatalysis and bioseperation Vol.5, New York, Wiley. pp- 2446-2462.

Christen, P., Angeles, N., Corzo, G., Farres, A., and Revah, S. 1995. Microbial lipase production on a polymeric resin, Biotechnol. Techniques, 9: 597-600.

Godoy, M.G., Gutarra, M.L.E., Castro, A.M., Machado, O.L.T, and Freire, D.M.G. 2011. Adding value to a toxic residue from the biodiesel industry: production of two distinct pool of lipases from Penicillium simplicissimum in castor bean waste, J. Industrial Microbiol. Biotechnol., 38(8): 945-953.

Gombert, A.K., Pinto, A.L., Castilho, L.R., and Freire, D.M.G. 1999. Lipase 
production by Penicillium restrictum in solid-state fermentation using babassu oil cake as substrate, Process Biochem., 35: 85-90.

Gopinath, S.C.B., Anbu, P., and Hilda, A. 2005. Extracellular enzymatic profiles in fungi isolated from oil-rich environments, Mycosci., 46: 119-126.

Goswami, D., De, S., and Basu, J.K. 2012. Effects of process variables and additives on mustard oil hydrolysis by porcine pancreas lipase. Brazilian $J$. Chem. Engi., 29: 449-460.

Ito, T., Kikuta, H., Nagamori, E., Honda, H., Ogino, H., Ishikawa, H., and Kobayashi, T. 2001. Lipase production in two-step fed batch culture of organic solvent-tolerant Pseudomonas aeruginosa LST-03, J. Biosci. Bioengi., 91: 245-250.

Kamini, N.R., Fujii, T., Kurosu, T., and Iefuji, H. 2000. Production, purification and characterization of an extracellular lipase from the yeast, Cryptococcus $s p$, S-2. Process Biochem., 36: 317-324.

Kumar, A.M., and Ray, P. 2014. Application of Plackett-Burman design for improved cold temperature production of lipase by psychrotolerant Pseudomonas sp.AKM-L5, Int. J. Curr. Microbiol. Appl. Sci., 3(4): 269-282.

Kurtzman, C.P., and Robnett, C.J. 1997. Identification of clinically important ascomycetous yeasts based on nucleotide divergence in the 5' end of the large-subunit (26S) ribosomal DNA gene, J. Clin. Microbiol., 35: 12161223.

Lanka, S., and Latha, J.N.L. 2015. Response surface methodology as a statistical tool for fermentation media optimization in lipase production by palm oil mill effluent (POME) isolate Emericella nidulans NFCCI 3643, Int. J. Innovative Res. Sci. Engi. Technol., 4(4): 25352545.
Mahadik, N.D., Puntambekar, U.S., Bastawde, K.B., Khire, J.M., and Gokhale, D.V. 2002. Production of acidic lipase by Aspergillus niger in solid state fermentation, Process Biochem., 38(5): 715-721.

Mander, P., Hah-Young, Y., Wook, K.S., Hee, C.Y., Sik, C.S., and Cheol, Y.J. 2014. Transesterification of waste cooking oil by an organic solventtolerant alkaline lipase from Streptomyces sp. CS273, Appl. Biochem. Biotechnol., 172(3): 1377 1389.

Melo, S.C.O., Pungartnik, C., Cascardo, J.C.M., and Brendel, M. 2006. Rapid and efficient protocol for DNA extraction and molecular identification of the basidiomycetes Crinipellis perniciosa, Genetics and Mol. Res., 5(4): 851-855.

Pereira, E.O., Tsang, A., McAllister, T.A., and Menassa, R. 2013. The production and characterization of a new active lipase from Acremonium alcalophilum using a plant bioreactor, Biotechnol. Biofuels, 6: 111.

Perrone, G., Varga, J., Susca, A., Frisvad, J.C., Stea, G., Kocsube, S., Toth, B., Kozakiewicz, Z., and Samson, R.A. 2008. Aspergillus uvarum sp. nov., an uniseriate black Aspergillus species isolated from grapes in Europe, Int. J. Systematics and Evol. Microbiol., 58: 1032-1039.

Plackett, R.L., and Burman, J.P. 1964. The design of optimum multi factorial experiments, Biometrika, 33(4): 305325.

Rivera-Munoz, G., Tinoco-Valencia, J.R., Sanchez, S., and Farres, A. 1991. Production of microbial lipases in solid state fermentation system, Biotechnol. Lett., 13: 277-280

Saitou, N., and Nei, M. 1987. The neighborjoining method: A new method for 
reconstructing phylogenetic trees, Mol. Biol. Evol., 4: 406-425.

Salgado, J.M., Abrunhosa, L., Venancio, A., Dominguez, J.M., and Belo, I. 2014. Integrated use of residues from olive mill and winery for lipase production using solid state fermentation with Aspergillus sp., Appl. Biochem. Biotechnol., 172: 1832-1845.

Salihu, A., Alam, M.Z., Abdul Karim, M.I., and Salleh, H.M. 2012. Lipase production: an insight in the utilization of renewable agricultural residues, Res. Conservation and Recycling, 58: 36-44.

Singh, A., and Mukhopadhyay, M. 2012. Microbial lipases from versatile tools for biotechnology, Trends in Biotechnol., 16: 396-403.

Singh, R., Gupta, N., Goswami, V.K., and Gupta, R. 2006. A simple activity staining protocol for lipases and esterase, Appl. Microbiol. Biotechnol., 70: 679-682.

Tamura, K., Peterson, D., Peterson, N., Stecher, G., Nei, M., and Kumar, S.
2011. MEGA5: Molecular evolutionary genetics analysis using maximum likelihood, evolutionary distance, and maximum parsimony methods, Mol. Biol. Evol., 28: 2731-2739.

Thompson, J., Higgins, D., and Gibson, T. 1994. CLUSTAL W. Improving the sensitivity of progressive multiple sequence alignment through sequence weighting position specific gap penalties and weight matrix choice, Nucleic Acids Res., 22(22): 4673-4690.

Vinod, K.N., Mary, E.R., Gunaseeli, R., and Kannan, N.D. (2014). Process optimization and production kinetics for cellulase production by Trichoderma viride VKF3, Springer Plus, 3: 92-104.

Vishwanatha, K.S., Apu-Rao, A.G., and Singh, S.A. 2010. Acid protease production by solid-state fermentation using Aspergillus oryzae MTCC 5341: optimization of process parameters, $J$. Industrial Microbiol. Biotechnol., 37: 129-138.

\section{How to cite this article:}

Nathan Vinod Kumar, Mary Esther Rani, R. Rathinasamy Gunaseeli and Narayanan Dhiraviam Kannan. 2017. Lipase Production using Aspergillus japonicus MF-1 through Biotransformation of Agro-Waste and Medicinal Oil Effluent. Int.J.Curr.Microbiol.App.Sci. 6(4): 2005-2020. doi: https://doi.org/10.20546/ijcmas.2017.604.237 